\title{
FORMULATION AND IN VITRO EVALUATION OF LAMOTRIGINE ORAL THIN FILMS
}

\author{
${ }^{1}$ Sanjay Kumar Gupta, ${ }^{1}$ Syed Amir Ali, ${ }^{2}$ Dr. Sradlhanjali Patra
${ }^{1}$ Shadan College of Pharmacy, Peerancheru, Hyderabad, 500091, Telangana
${ }^{2}$ University Department of Pharmaceutical Sciences, Utkal University, Bhubaneswar, Odisha \\ Corresponding Author: \\ *Sanjay Kumar Gupta \\ Associate professor,Department of Pharmaceutics \\ Shadan College of Pharmacy, Hyderabad,Telangana-500091
}

\section{ABSTRACT}

There is rapidly dissolving dosage forms have great important in the pharmaceutical industry due to their unique properties and advantage. The objectives of the present study is to design and evaluate fast dissolving films of lamotrigine using HPMC different grade with an aim to achieve rapid drug release thereby controlling the seizures in the shortest possible time. The films were prepared by the solvent casting method using different concentration of sodium starch glycolate (SSG) as a super disintegrate,croscarmellose sodium(CCS),hydroxypropyl methylcellulose (HPMC), carboxy methyl cellulose (CMC), Polyethylene glycol (PEG-400), vanilla as a flavoring agent and aspartame as sweetening agent. The prepared first dissolving film was evaluated both physically characterization thickness, weightvariation, drug content, disintegration time, in vitro dissolution study, folding endurance and surface $\mathrm{pH}$. The drugexcipient compatibility study was performed by using FT-IR.All the planned seven (L1L7)formulations indicate attractive film parameter but optimized formulation (L4) was gave 98.7\% of drug release at $15 \mathrm{~min}$. The formulation L4 gave satisfactory $\mathrm{pH}(6.2 \pm 0.2)$, drug content $(98.9 \pm 0.5 \%)$, the disintegration time of $3.0 \pm 0.1$ seconds and film thickness $(0.17 \pm .002 \mathrm{~mm})$.The compatibility study was performed on optimized formulation L4 by using FT-IR whish revealed that there was absence of any type of interaction between the drug and excipient. The 3 months stability study was carried as per ICH guidelines found that there is no significant change on optimized formulation L4.

Key word:Oral fast dissolving film (OFDF),Croscarmellose sodium (CCS), FT-IR,SolventCasting Method

\section{INTRODUCTION:}

Among all routes of drug administration, the oral route is one of the most favored routes.Oral course is the most favored course for the conveyance of the medications till date as it bears different focal points over the other course of medication organization, however oral medication conveyance frameworks still need a few headways to be made in light of their a few disadvantages identified with specific class of patients which incorporates geriatric, pediatric and dysphagia patients related with numerous restorative conditions as they experience issues in gulping or biting strong dose shapes[1,2]. There are many of the pharmaceutical industry focusing their research on rapid dissolving technology. Oral course 
is the most favored course for the conveyance of the medications till date as it bears different focal points over the other course of medication organization. Oral fast dissolving film (OFDF) is one such novel approach to increase consumer acknowledgment by temperance of quick disintegration, self-organization without water or chewing. The film is a perfect intraoral quick dissolving drug conveyance framework, which fulfills the neglected needs of the market, is anything but difficult to deal with and oversee, keeps up a basic and advantageous bundling, lightens repulsive taste, and is clear to fabricate.

Buccal drug delivery recently becomes an important route of drug administration in which problems like high first-pass metabolism and drug degradation in the gastrointestinal environment can be avoided by administering the drug through buccal route.Thus, fast dissolving films allow the films to dissolve in the mouth, so the drug gets directly absorbed into the systemic circulation through the oral mucosa [3].Innovative work in the oral medication conveyance section has prompted change of measurement frames from basic regular tablets or cases to altered discharge tablets or containers to oral disintegration tablet (ODT) to wafer to the current improvement of oral first dissolving films (OFDFs). Among the plenty of roads investigated for the fast medication discharging items, oral strip innovation is increasing much attention $[6,7]$. (OFDT) was at thatpoint well known among the general population in the mid 2000 year with the presentation and far reaching utilization of Listerine take strips, another dispatch in the mouthwash run. Innovation Catalysts figures the market for medicates items in oral thin film details to be esteemed at $\$ 500$ million of every 2007 and could reach $\$ 2$ billion in close future [7, 8, 12]. However just a couple of items comprising unpleasant particles have possessed the capacity to be popularized in light of the multifaceted nature related with the ODT.Oral fast dissolving film (OFDF) is one such novel approach to increase consumer acknowledgment by temperance of quick disintegration, self-organization without water or chewing. The film is a perfect intraoral quick dissolving drug conveyance framework, which fulfills the neglected needs of the market, is anything but difficult to deal with and oversee, keeps up a basic and advantageous bundling, lightens repulsive taste, and is clear to fabricate. The film is set on the best or the floor of the tongue. It is held at the site of use and quickly discharges the dynamic operator for neighborhood or potentially foundational absorption. The improvement of a quick dissolving film likewise gives a chance to a line augmentation in the commercial center, an extensive variety of medications (e.g., neuroleptics, cardiovascular medications, analgesics, antihistamines, antiasthmatic and drugs for erectile brokenness) can be considered possibility for this dose form $[7,10-16]$.

Epilepsy is a neurological disorder which requires quick management of seizures in order to avoid the risk of permanent brain damage.More than 5.2crores of people suffer with epilepsy of which only some 1.6crores people avail proper therapy.Thus it is necessary to develop fast dissolving films for the anti-epileptic drugLamotrigine is a new antiepileptic drug, which acts by blocking voltage-dependent sodium channel, and reducing the release of excitatory neurotransmitters, particularly glutamate and aspartate to bring brain back to orderliness.

\section{MATERIAL AND METHODE: \\ Material:}

Materials used in this study were obtained from different sources. Lamotrigine a gift sample from Chandra Lab, Hyderabad.Hydroxy propyl methyl cellulose (HPMC), carboxyl methyl cellulose (CMC) procured from Drug India Pvt.Ltd.Croscarmellose sodium (CCS), sodium starch glycolate (SSG), Polyethylene glycol (PEG-400), vanilla and aspartame were procured from S.D. Fine Chem. Ltd., Mumbai. 


\section{Preformulation study:}

It is an investigation of physical and chemical properties of a drug substance alone and when combined with excipients uses of which maximizes the chances in formulating an acceptable, safe, efficacious and stable product [16-17].

Pre-formulation studies were carried out to serve following purposes:

i) To finalize specifications of active pharmaceutical ingredients (API)

ii) To Study the compatibility between active and inactive ingredient

iii) Characterization of reference product

It is divided in to two Subclasses.

1. API characterization,

2. Compatibility study

\section{Characterization of Lomatrigine:}

These are preliminary characteristics of any substance which is useful in identification of specific material. Physical properties of API were studied like organoleptic properties, melting point and solubility etc. The result was tabulated in table $2,3 \& 4$.

\section{Drug Excipient Compatibility Studies:}

Study was completed utilizing FT-IR spectrometer by the $\mathrm{KBr}$ pellet technique in the wavelength between range of 400 and $4000 \mathrm{~cm}-1$ [23-24]. FT-IR Spectra of Lamotrigine alone and optimize formulation (L4) were recoded. The range was considered for particular pinnacles of medication and polymer. The spectrum of FT-IR is shown in fig- $2 \& 3$.

\section{Determination of $\lambda \max$ of Lamotrigine:}

Accurately weighed $100 \mathrm{mg}$ of Lamotrigine and transferred into $100 \mathrm{ml}$ of volumetric flask and dissolved in small quantity of methanol and diluted with $\mathrm{pH} 6.8$ phosphate buffer up to the mark to give stock solution $1 \mathrm{mg} / \mathrm{ml}(100 \mu \mathrm{g} / \mathrm{ml}) .1 \mathrm{ml}$ was taken from stock solution in another volumetric flask and diluted up to $10 \mathrm{ml}$ to give a stock solution $100 \mu \mathrm{g} / \mathrm{ml}$ was examined between $200-400 \mathrm{~nm}$. The $\lambda$ max was observed to be $250 \mathrm{~nm}$ and utilized as logical wavelength [25-26]. The spectrum as shown in fig-2

\section{Preparation of Calibration curve of Lamotrigine in pH 6.8 phosphate buffer:}

From the above solution dilutions were made in phosphate buffer $\mathrm{pH} 6.8$ in order to get 5,10 , $15,20,25 \mu \mathrm{g} / \mathrm{ml}$ Absorbance of these dilutions were measured at $\lambda$ max $250 \mathrm{~nm}$ using UVVisible spectrophotometer and standard curve was plotted. The curve is shown in fig- 1.

\section{FORMULATION OF LAMOTRIGINE FAST DISSOLVING ORAL FILM:}

\section{Calculation of dosage for Lamotrigine:}

Measurement of the glass Petri dish diameter $=4.8 \mathrm{~cm}$

Zone area ofthe glass petri dish $=\pi \mathrm{r}^{2}=18 \mathrm{~cm}^{2}$

No. of $6 \mathrm{~cm}^{2}(3 \times 2 \mathrm{~cm})$ strip films display in entire plate $=18 / 6=3$

Each film contains $35 \mathrm{mg}$ of medication

3 no. of films contains Lamotrigine $=3 \times 35=105 \mathrm{mg}$

The measure of medication included each plate was around equivalent to $105 \mathrm{mg}$.

\section{Preparation of Lamotrigine by Solvent-Casting Method:}

The Oral quick dissolving films were set up by dissolving strip framing operators and plasticizer in the refined water, at that point arrangement was constantly mixed up to 4 hours on attractive stirrer ${ }^{[9,10,12,26]}$ and kept for 1 hour to expel all the air bubbles ensnared. Then, in the different compartment remaining water solvent excipients i.e. sweetening specialist, 
flavor and medication were disintegrated with steady blending for $45 \mathrm{~min}$. At the point when the mixing was over both the arrangements were combined with blending for an additional 1 hour on attractive stirrer. At that point the arrangement was kept stationary for 1 hour to give the froths a chance to settle down [24-30]. The subsequent plan was cast on to a glass petri dish of surface zone $18 \mathrm{~cm} 2$ dried for 24 hours at room temperature. The film was expelled from the plate painstakingly and watched for any defects. Film of territory $6 \mathrm{~cm}^{2}(2 \times 3)$ was cut and put away in a spread paper and securedwith aluminum thwart and put away in a desiccator. Different formulation was prepared by incorporating different concentration of HPMC, CMC, SSG and CCS.

Table - 01: Formulation design

\begin{tabular}{|c|c|c|c|c|c|c|c|c|}
\hline S.N & Ingredients & L1 & L2 & L3 & L4 & L5 & L6 & L7 \\
\hline 1 & Lamotrigine & 35 & 35 & 35 & 35 & 35 & 35 & 35 \\
\hline 2 & SSG & $0.5 \%$ & - & $1 \%$ & - & $0.5 \%$ & - & $1 \%$ \\
\hline 3 & CCS & - & 0.5 & - & $1 \%$ & - & $0.5 \%$ & - \\
\hline 4 & HPMC & $3 \%$ & $4 \%$ & $3 \%$ & $3 \%$ & - & - & - \\
\hline 5 & CMC & - & - & - & - & $3 \%$ & $4 \%$ & $4 \%$ \\
\hline 6 & PEG-400 & $0.1 \%$ & 0.1 & $0.1 \%$ & $0.1 \%$ & $0.1 \%$ & $0.1 \%$ & $0.1 \%$ \\
\hline 7 & Vanillin & $0.2 \%$ & 0.2 & $0.2 \%$ & $0.2 \%$ & $0.2 \%$ & $0.2 \%$ & $0.2 \%$ \\
\hline 8 & Aspartame & $0.2 \%$ & 0.2 & $0.2 \%$ & $0.2 \%$ & $0.2 \%$ & $0.2 \%$ & $0.2 \%$ \\
\hline \multicolumn{2}{r}{} \\
Inference & $\begin{array}{c}\text { Film not } \\
\text { formed }\end{array}$ & $\begin{array}{c}\text { Film } \\
\text { formed }\end{array}$ & $\begin{array}{c}\text { Film } \\
\text { formed }\end{array}$ & $\begin{array}{c}\text { Film } \\
\text { formed }\end{array}$ & $\begin{array}{c}\text { Film not } \\
\text { formed }\end{array}$ & $\begin{array}{c}\text { Film } \\
\text { formed }\end{array}$ & $\begin{array}{c}\text { Film formed } \\
\text { formed }\end{array}$ \\
\end{tabular}

\section{EVALUATION FILMS:}

\section{Weight variation of the film:}

$2 \times 3 \mathrm{~cm}^{2}$ film was cut at five better places in the threw film. The heaviness of each filmstrip was taken and the weight variation $[27,28]$ was figured and the outcomes are given in the table no.06

\section{Thickness of the film:}

The thickness of the fix was estimated utilizing advanced Vernier Callipers with a minimum check of $0.01 \mathrm{~mm}$ at various spots of the film. The thickness was estimated at three unique spots of the film [26-28] and normal was taken and SD was ascertained and given in the table no.06.

\section{Folding endurance:}

The collapsing perseverance is communicated as the number of folds required to break the strip. This gives a sign of weakness of the film. A little piece of $2 \times 3$ square $\mathrm{cm}$ was subjected to this test by collapsing the film at the same plane[26-29] over and again a few times until the point that an obvious break was watched and the outcomes are appeared in the table no06.

pH:The $\mathrm{pH}$ was controlled by dissolving a film in $2 \mathrm{ml}$ of distilled water andafter that the $\mathrm{pH}$ of the acquired arrangement was estimated by $\mathrm{pH}$ paper[26-28]. 


\section{Content Uniformity:}

Drug content consistency of every one of the seven clumps was controlled by UV Spectrophotometric technique. For this, each strip at three better places identical to $35 \mathrm{mg}$ of medication was cut and broke down in $50 \mathrm{ml}$ of $6.8 \mathrm{pH}$ phosphate buffer with consistent mixing. This arrangement was separated utilizing Whattmann filter paper, and the filtrate was made up to $100 \mathrm{ml}$ with $6.8 \mathrm{pH}$ phosphate buffer. This arrangement was investigated by UV Spectrophotometer and the absorbance [29-31] was recorded at 250nm. The outcomes were outlined in table no-06.

\section{Disintegration time:}

Test was performed utilizing deterioration test mechanical assembly. $2 \times 3 \mathrm{~cm}^{2}$ film was put in the bin, brought and brought down it up. Time required by the film, when no hints of film[16, 17] stay over the dressing was noted. Test was performed in triplicate and the outcomes are accounted for in the table no-06.

\section{Invitro Dissolution studies:}

Drug release from OFDFs was studied by using USP Type1 dissolutiontest apparatus. OFDFs of desired formulation were placed in the vessels of dissolution apparatus. Samples were collected at time intervals of $2,5,10,15,20,25,30,40$ and $60 \mathrm{~m}$, replenished with equal volume of the blank solution. The samples were filtered immediately and analyzed spectrophotometrically at 250nm [15-17]. Cumulative percentage Lamotrigine released was calculated and plotted against time. The outcomes are given in the table no.07.

\section{Kinetic analysis of in vitro release data:}

In order to determine the release mechanism that provides the best description to the pattern of drug release, the in vitro release data were fitted to zero order, first-order, Hixson Crowell, and Korsemeyer-Peppasmodel [35-38].The data of regression coefficient of different kinetic models were summarized in table no-08.

\section{Stability Studies:}

The optimized batch F5 was packed in a butter paper covered with aluminum foil and was isothermally stressed to study the stability under accelerated temperature and relative humidity conditions carried out at $40^{\circ} \mathrm{C} / 75 \% \mathrm{RH}, 25^{\circ} \mathrm{C} / 60 \% \mathrm{RH}$ and $25^{\circ} \mathrm{C} / 40 \% \mathrm{RH}$ for a period of 3 months[41-43]. Test samples were withdrawn every month and were subjected to various tests including visual inspection of the film, disintegration time and cumulative percent of drug release. The results are given in Table- 09 .

\section{RESULT AND DISCUSSION:}

\section{Preformulation Study:}

\section{A. Organoleptic Properties (Color, odor, taste and appearance)}

Table- 02. Results of identification tests of drug

\begin{tabular}{|c|c|c|}
\hline S.NO & Parameter & Drug \\
\hline $\mathbf{1}$ & Color & White to off white powder \\
\hline $\mathbf{2}$ & Odor & Odorless \\
\hline $\mathbf{3}$ & Taste & Tasteless \\
\hline $\mathbf{4}$ & Appearance & Crystalline powder. \\
\hline
\end{tabular}




\section{B. Melting point determination of Drug: Lamotrigine}

Table 03: Results of Melting point determination test of drug

\begin{tabular}{|c|c|}
\hline DRUG NAME & Observed Melting Point \\
\hline Lamotrigine & $216-218^{0} \mathrm{c}$ \\
\hline
\end{tabular}

\section{Solubility}

Results of the tests are illustrated in the table

Table no 04: Table showing the Solubility of Lamotrigine (API) in various solvents.

\begin{tabular}{|c|c|}
\hline Solvents & Solubility \\
\hline Water & Slightly soluble \\
\hline pH6.8 Phosphate buffer & Soluble \\
\hline Methanol & Soluble \\
\hline Acetone & InSoluble \\
\hline
\end{tabular}

\section{Standard Calibration Curve}

In the pre-formulation study, it was found that the $\lambda \max$ of Lamotrigine by spectrophotometric method in phosphate buffer $\mathrm{pH} 6.8$ was found to be $250 \mathrm{~nm}$. The spectrum were shown in fig-01

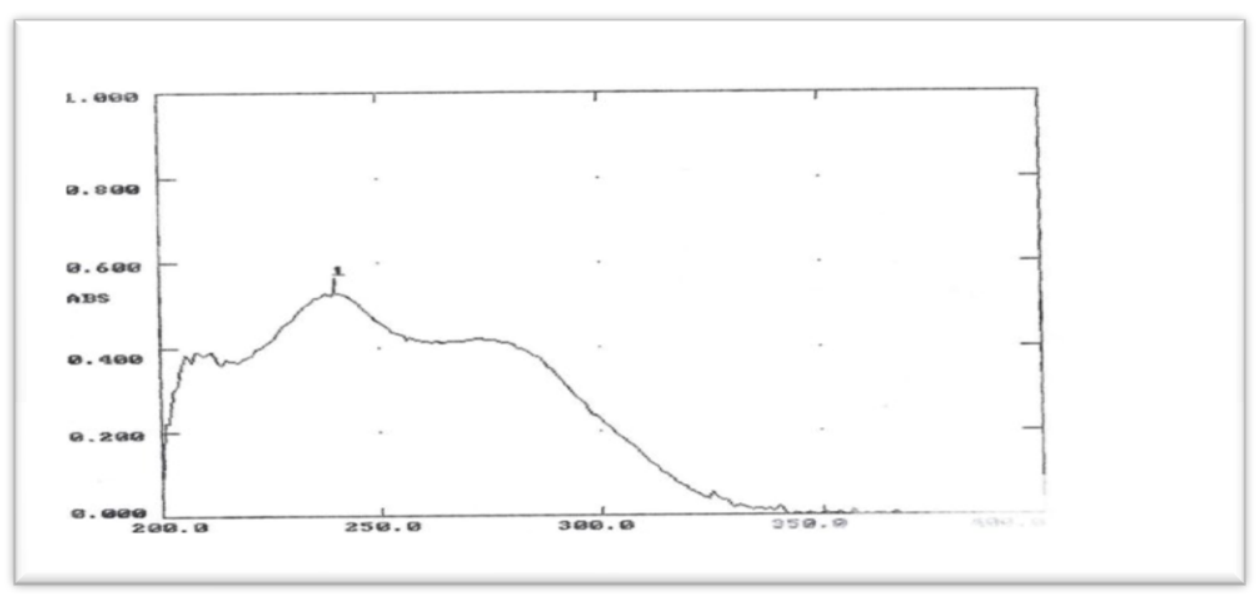

Fig no- 01 UV Spectrum for Lamotrigine at 250n

Table 05: Calibration Curve of Lamotrigine in Phosphate Buffer pH 6.8

\begin{tabular}{|c|c|}
\hline Concentration $(\boldsymbol{\mu g} / \mathrm{ml})$ & Absorbance \\
\hline 0 & 0 \\
\hline 5 & 0.101 \\
\hline 10 & 0.184 \\
\hline 15 & 0.277 \\
\hline 20 & 0.370 \\
\hline 25 & 0.460 \\
\hline
\end{tabular}




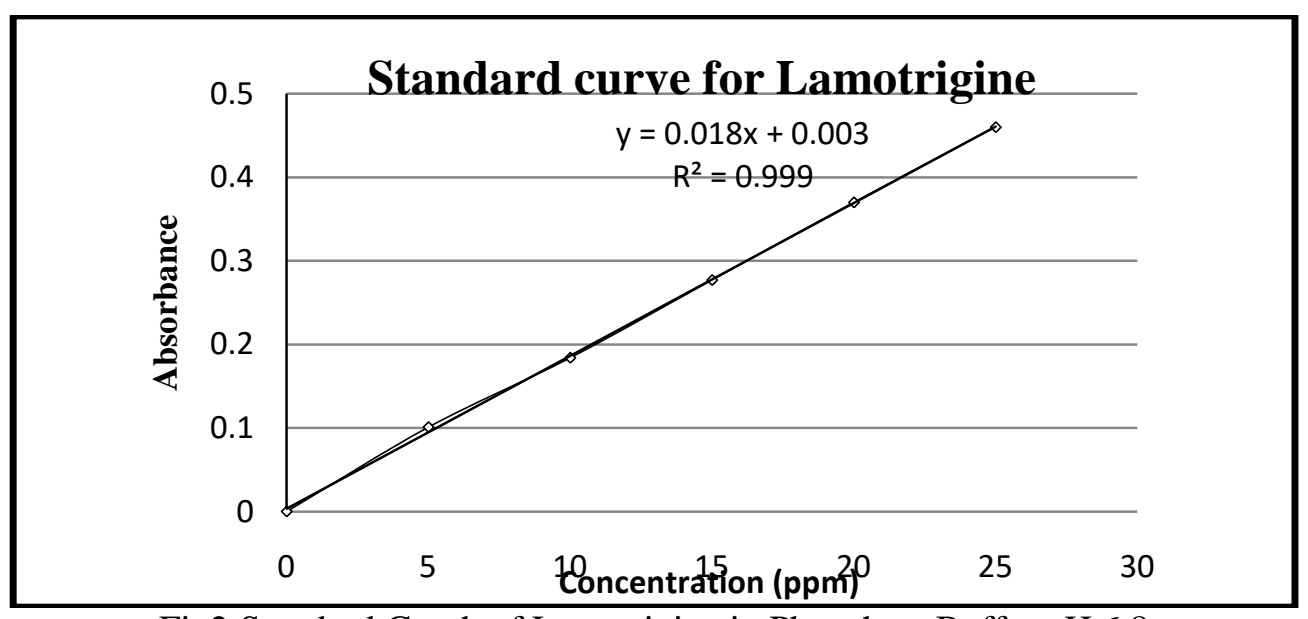

Fig2:Standard Graph of Lamotrigine in Phosphate Buffer pH 6.8

\section{E. Drug polymer compatibility studies:}

FTIR studies conducted on pure drug and the optimize formulation (L4) given in Figures 3 and 4 , which showed that, there is no marked interaction between drug and excipients used.

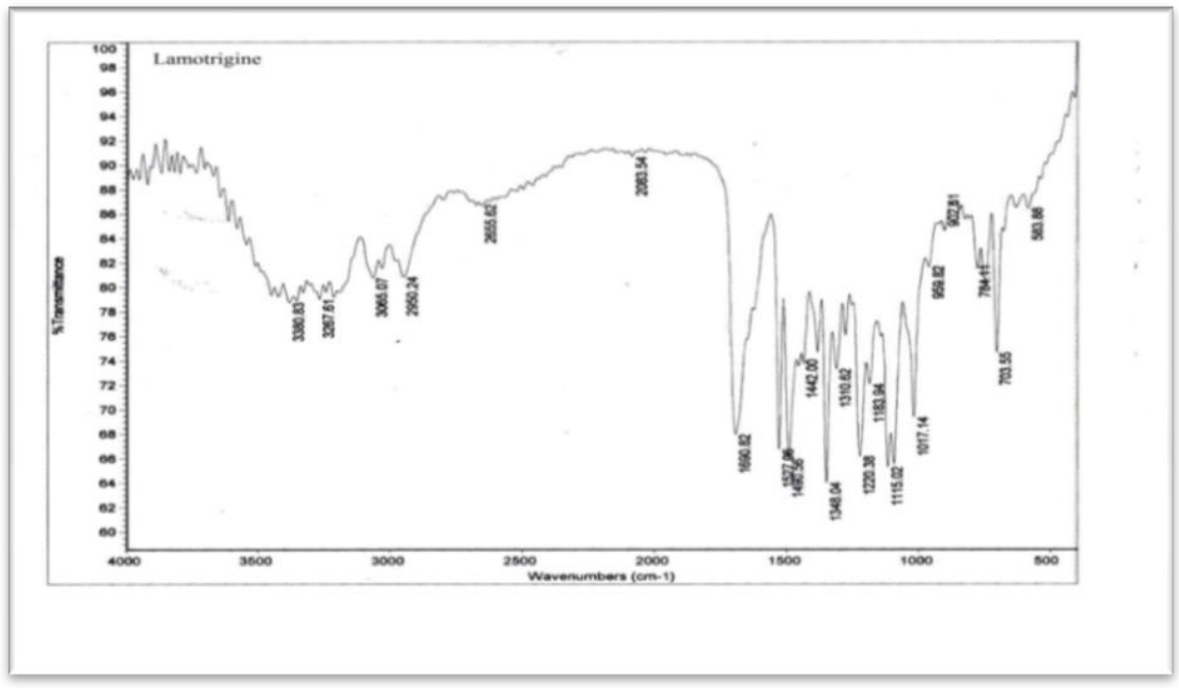

Fig no-3FTIR spectra of Lamotrigine Pure Drug

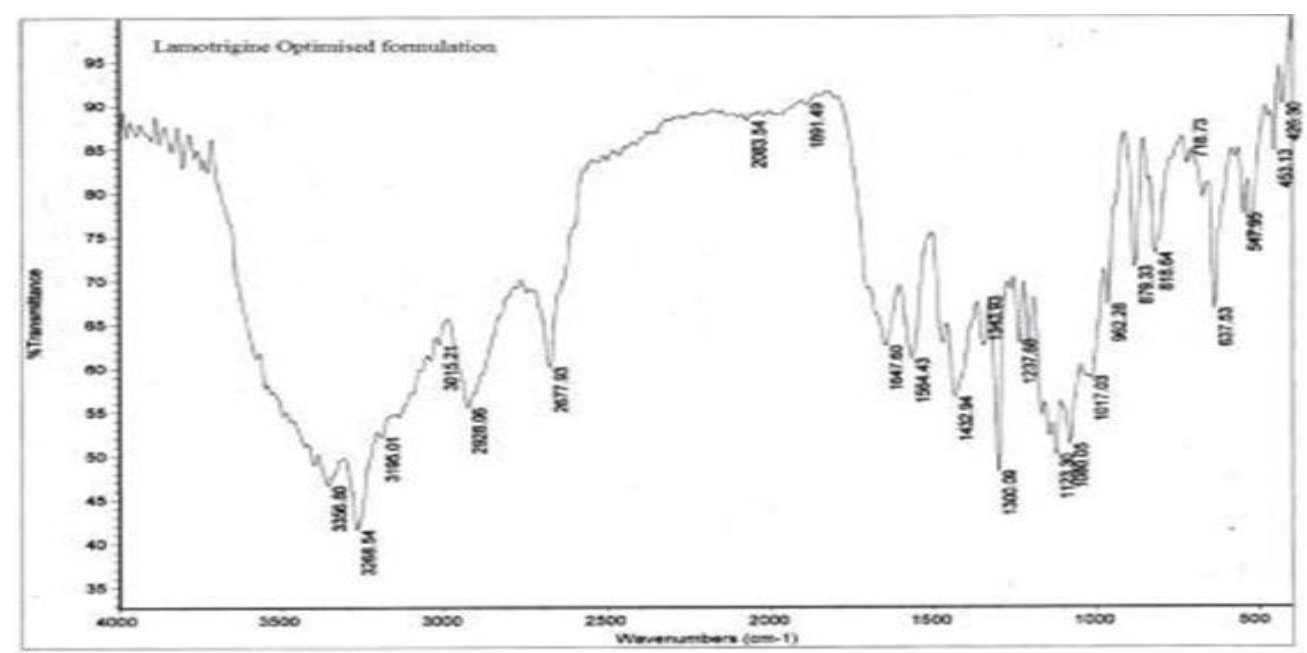

Fig No-04 FTIR spectraof Lamotrigine optimize formulation (L4) 


\section{Characterizationof Lamotrigine Fast Dissolving Oral Films}

\subsection{Weight Variation test}

The weights of the films were observed to be in the range of $197 \mathrm{mg}$ to $206 \mathrm{mg}$.

Theaftereffects of normal weight of all films were compressed.

\subsection{Physical app}

\section{earance and surface}

The perception by visual examination of films and by feel or touch, recommends that the films are having smooth surface and they are sufficiently rich to see.

\subsection{Thickness of films}

The thicknesses of the films were in the scope of to $0.16 \mathrm{~mm}$ to $0.29 \mathrm{~mm}$. The consequences of normal thickness of all films were abridged in table no.6.

\subsection{Folding endurance number:}

Folding continuance of the films was observed to be in the scope of 98 to108. The aftereffects of normal collapsing continuance of all films were outlined in table no.06.

\subsection{In-vitro disintegration test:}

The disintegration times were in the range of $3 \mathrm{~min}$ to $6 \mathrm{~min}$. The results of average disintegration time of all films were summarized in table no-07

\subsection{Drug content test:}

Drug contentis performed by taking three films in every detailing trial and the normalmedication content was ascertained. The outcomes were observed to be in the scope of $94.4 \%$ to $98.9 \%$. The consequences of normal medication substance of all films were condensed in table no.06.

Table 4: Evaluation of Lamotrigine Films (L1 to L7)

\begin{tabular}{|c|c|c|c|c|c|}
\hline $\begin{array}{c}\text { Formulation } \\
\text { Code }\end{array}$ & $\begin{array}{c}\text { Weight variation } \\
\text { in } \mathbf{~ m g}\end{array}$ & $\begin{array}{c}\text { Thickness } \\
\text { in } \mathbf{~ m m}\end{array}$ & $\begin{array}{c}\text { Folding } \\
\text { endurance }\end{array}$ & $\begin{array}{c}\text { Drug content } \\
\text { in \% }\end{array}$ & $\begin{array}{c}\text { Disintegrati } \\
\text { on time }\end{array}$ \\
\hline L1 & 206 & 0.22 & 103 & 97.2 & 4 min \\
\hline L2 & 203 & 0.29 & 108 & 95.8 & $6 \mathrm{~min}$ \\
\hline L3 & 201 & 0.18 & 106 & 95.6 & $3 \mathrm{~min}$ \\
\hline L4 & 198 & 0.17 & 98 & 98.9 & $3 \mathrm{~min}$ \\
\hline L5 & 197 & 0.16 & 101 & 96.8 & 5 min \\
\hline L6 & 205 & 0.21 & 104 & 94.4 & 2 min \\
\hline L7 & 206 & 0.22 & 101 & 96 & 3 min \\
\hline
\end{tabular}

\subsection{In-vitro dissolution test:}

In-vitro drug release studies in $6.8 \mathrm{pH}$ phosphate buffer show drug release from range $65.8 \%$ to $98.7 \%$ all film formulation with in $15 \mathrm{~min}$. The plots of \% aggregate Lamotrigine release versus time (min) were plotted and delineated as appeared in Fig.05. The formulation L4 indicated higher release rate of $98.7 \%$ uncovering that films made with convergences of 
HPMC, $3 \% \mathrm{w} / \mathrm{v}$ and CCS $1 \% \mathrm{w} / \mathrm{v}$. As higher dissolution rate helps in quicker beginning of activity, L4 was picked as the improvedformulation.

Table 07: In-vitro drug release data of formulation L1 to L7

\begin{tabular}{|c|c|c|c|c|c|c|c|}
\hline $\begin{array}{c}\text { Time in } \\
\text { min }\end{array}$ & L1 & L2 & L3 & L4 & L5 & L6 & L7 \\
\hline $\mathbf{2}$ & 16.8 & 12.6 & 20.3 & 36.3 & 14.3 & 10.5 & 21.8 \\
\hline $\mathbf{4}$ & 31.8 & 28.7 & 35.7 & 49.3 & 29.8 & 25.6 & 37.2 \\
\hline $\mathbf{6}$ & 43.6 & 40.1 & 47.8 & 61.8 & 42.7 & 38.6 & 48.3 \\
\hline $\mathbf{8}$ & 51.8 & 47.2 & 56.3 & 70.6 & 49.6 & 45.08 & 57.6 \\
\hline $\mathbf{1 0}$ & 60.1 & 58.2 & 65.8 & 80.03 & 59.5 & 55.7 & 66.9 \\
\hline $\mathbf{1 5}$ & 71.6 & 69.3 & 76.3 & 98.7 & 70.2 & 65.8 & 77.8 \\
\hline
\end{tabular}

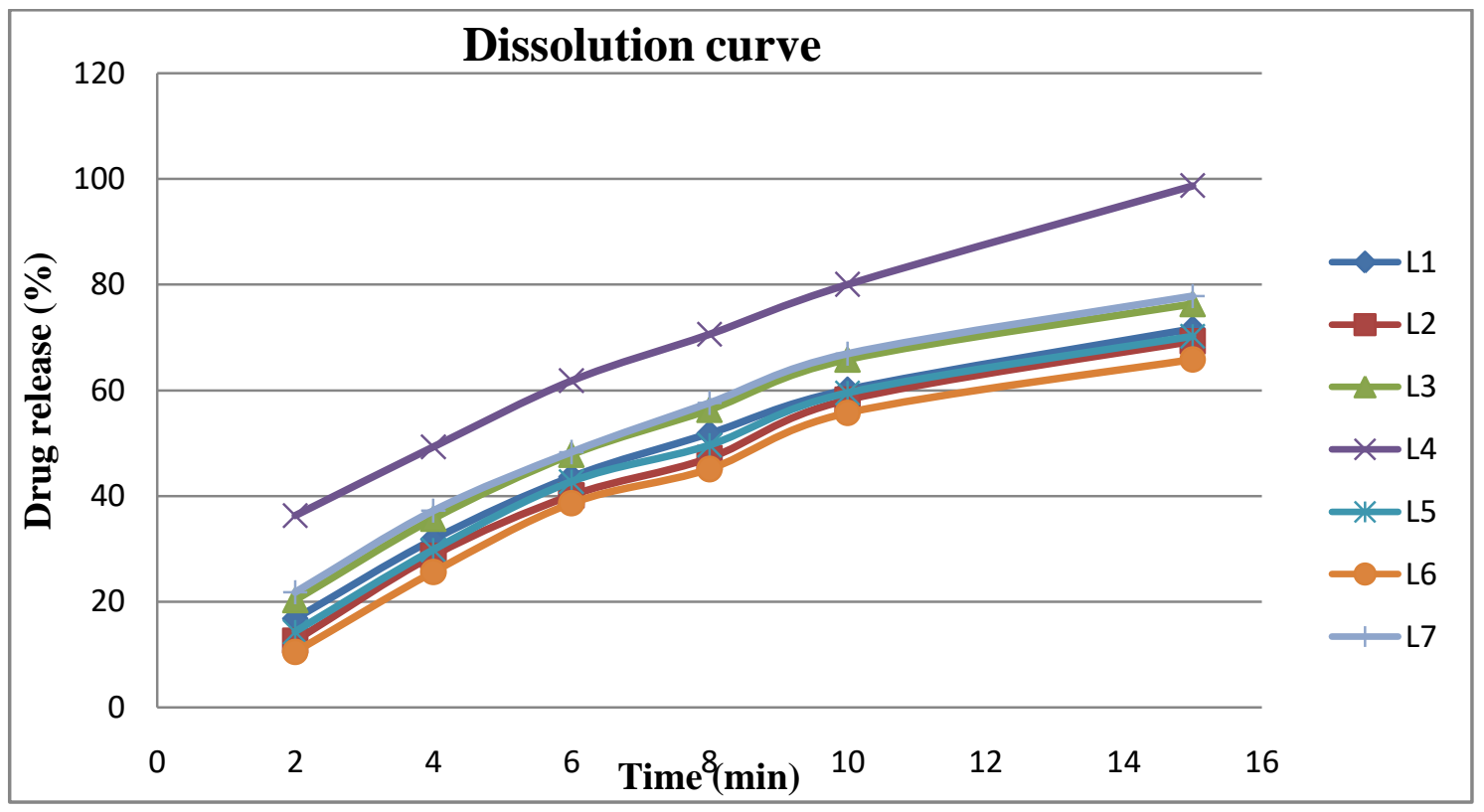

Fig no- 05In-vitro drug release of formulations L1-L7

\subsection{Data analysis (Curve fitting analysis):}

For analyzing therelease mechanism, the data obtained were fitted to various kinetic equations of Zero order, First order, Higuchi model and Korsmeyer - Peppas model. The regression coefficient is calculated. The data of regression coefficient of different kinetic models were summarized in table no.08. 


\section{Table 08:Regression data}

\begin{tabular}{|c|c|c|c|c|}
\hline & ZERO & FIRST & HIGUCHI & PEPPAS \\
\hline & \% CDR Vs T & $\begin{array}{c}\text { Log \%of drug } \\
\text { release Vs T }\end{array}$ & \%CDR Vs $\sqrt{ }$ T & LogC Vs Log T \\
\hline Slope & 6.00733945 & -0.11398717 & 25.54912993 & 0.49912782 \\
\hline Intercept & 18.13853211 & 2.156477161 & -0.19652700 & 0.56741021 \\
\hline Correlation & 0.950970768 & -0.93512452 & 0.999691507 & 0.851049545 \\
\hline $\mathbf{R}^{2}$ & 0.904345402 & 0.873357878 & 0.99953831 & 0.7255285328 \\
\hline
\end{tabular}

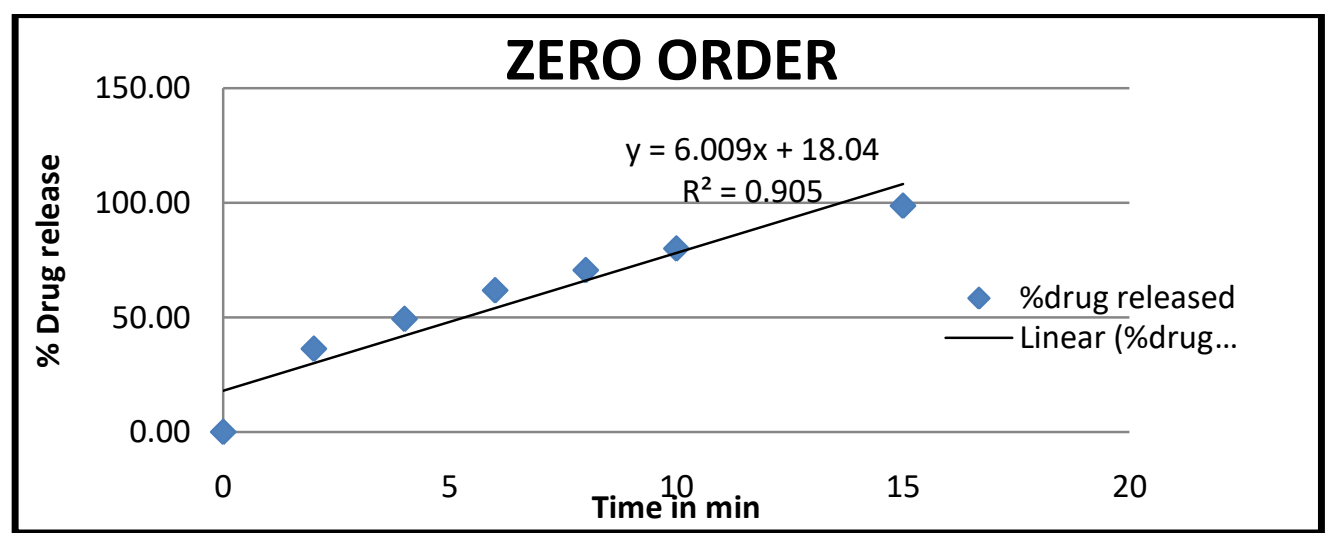

Fig no- 06 Zero order kinetics

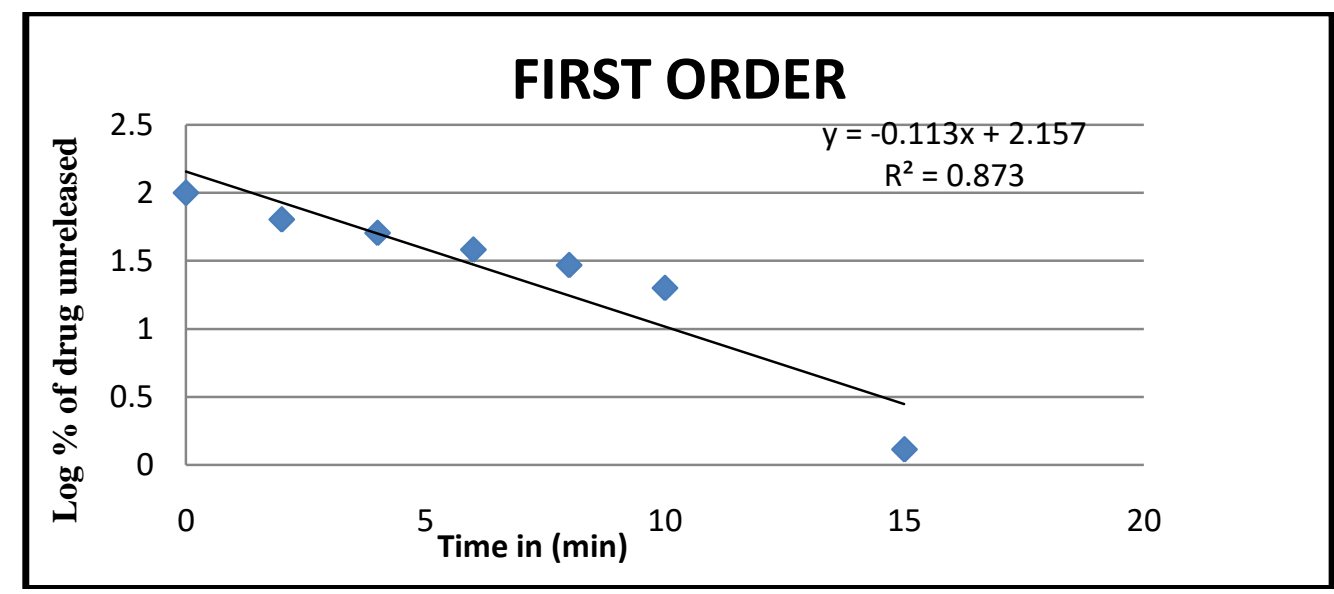

Fig no-07First order kinetics

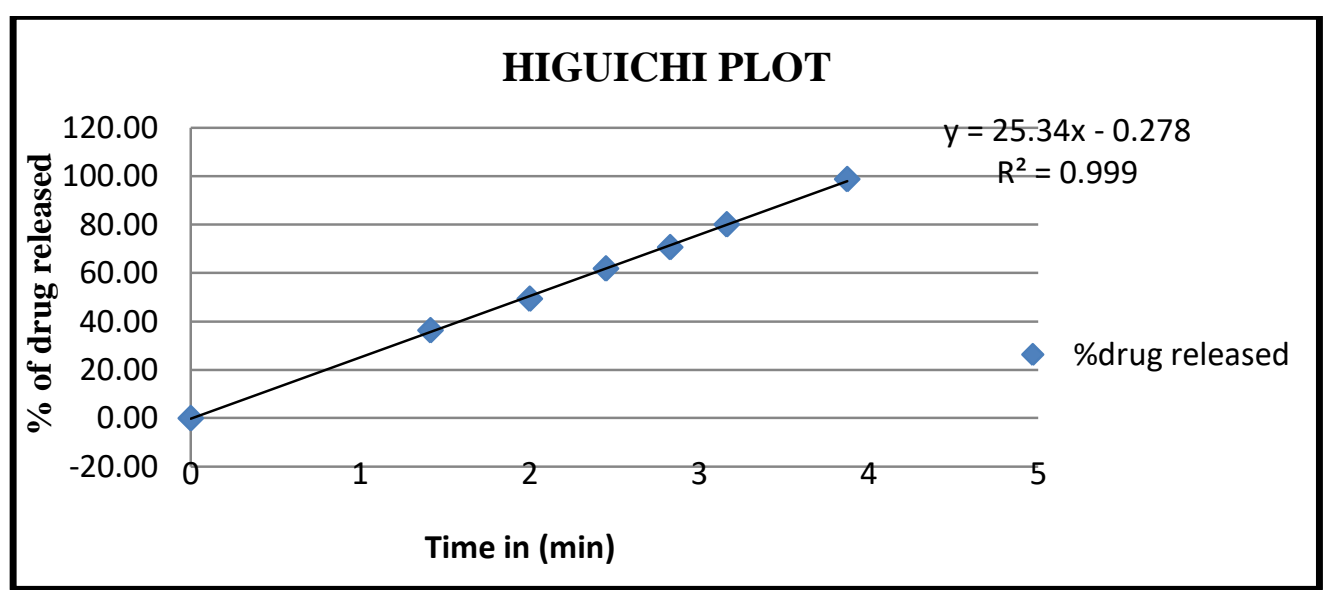

Fig no-08Higuchi order kinetics 


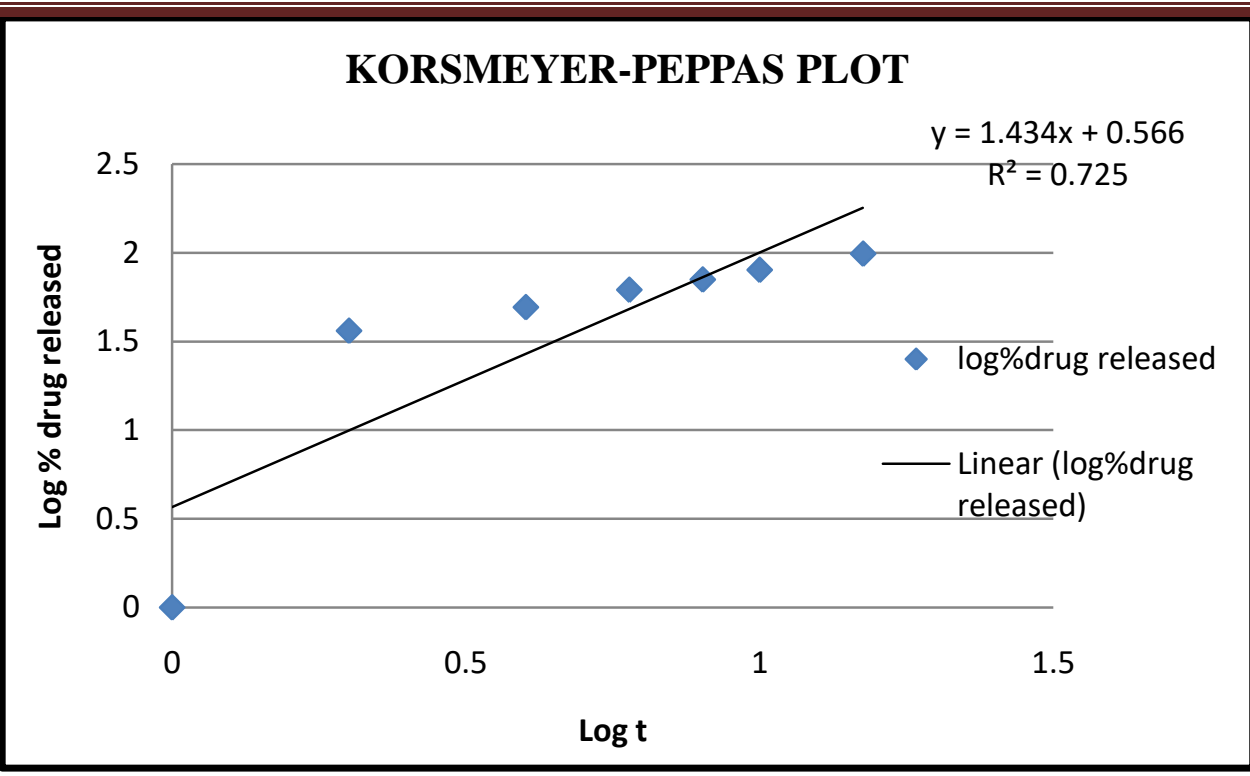

\subsection{Stability studies}

Fig no-09 Korsmeyer-Peppas Model plot

The formulation of L4 was evaluated for stability studies which was stored at $40^{\circ} \mathrm{C} / 75 \% \mathrm{RH}$ for 3 months and evaluated for their physical appearance, drug content anddisintegration time and $\%$ drug release at the end of $1^{\text {st }}$ and $3^{\text {rd }}$ month. The results were summarized in table no.09

Table 9: Stability data of formulation L4

\begin{tabular}{|c|c|c|c|}
\hline \multicolumn{6}{|c|}{ Formulation $\mathbf{L 5}$ stored at $\mathbf{4 0}{ }^{\circ} \mathbf{C}$ / 75\% $\mathbf{~ R H ~}$} \\
\hline $\begin{array}{c}\text { Time in } \\
\text { month }\end{array}$ & Physical Appearance & $\begin{array}{c}\text { Disintegrationti } \\
\text { me(sec) }\end{array}$ & \% Drug release \\
\hline Initial & Transparent\&acceptable & 4 & 98.7 \\
\hline 1 month & Transparent\&acceptable & 5 & 98.4 \\
\hline $\begin{array}{c}\text { End of } 3^{\text {rd }} \\
\text { month }\end{array}$ & Transparent\&acceptable & 4 & 98.1 \\
\hline
\end{tabular}

\section{SUMMARY AND CONCLUSION:}

In current research work, an effort has been made to prepare Fast dissolving Lamotrigine oral film by solvent casting method. Pre formulation study involving FTIR study showed no interaction between drug and polymer.Fast dissolving films prepared in the study exhibited good film characteristic features as indicated by thickness measured, folding endurance, disintegration time, tensile strength and drug content. The prepared films containing $3 \% \mathrm{w} / \mathrm{v}$ of HPMC and 1\% CCS film(formulation L4) showed $98.7 \%$ of drug was released by in 15 minutes which was desirable for fast absorption. As compared to that conventional dosage form, Fast dissolving Film has rapid onset of action.Data obtained from correlation coefficient and slope values revealed that drug release from formulation followed Higuchi model kinetic $\left(\mathrm{R}^{2}=0.9995\right)$,indicating diffusion as the release mechanism and " $\mathrm{n}$ " $=0.49$ indicate anomalous diffusion or non fickian diffusion. The optimized batch L4 was found to be stable for a period 3 months accelerated stability study at $40^{\circ} \mathrm{C} / 75 \% \mathrm{RH}$. From the present examination it can be presumed that oral quick dissolving film definition can be a potential novel medication measurement frame for pediatric, geriatric and furthermore for all inclusive community for management of epilepsy. 


\section{REFERENCES:}

1. Ishikawa $\mathrm{T}$, Koizumi N, Mukai B. Pharmacokinetics of acetaminophen from rapidly disintegrating compressed tablet prepared using microcrystalline cellulose (PHM06) and spherical sugar granules. Chem Pharm Bull (Tokyo) 2001; 49: 230-32.

2. Price TM, Blauer KL, Hansen M, Stanczyk F, Lobo R, Bates GW. Singledose pharmacokinetics of sublingual versus oral administration of micronized 17 beta estradiol.ObstetGynecol 1997; 89: 34045.

3. R.P Walton Absorption of drugs through the oral mucosa. III Fat water solubility coefficient of alkaloids.ProcSocExp Bio Med 1935; 32: 1488.

4.Kurosaki Y, Takatori T, Nishimura H, Nakayama T, Kimura T . Regional variation in oral mucosal drug absorption permeability and degree of keratinization in hamster oral cavity.Pharm Res 1991; 8: 1297-1301.

5. Ghosh TK, Chatterjee DJ, Pfister WR. Quick dissolving oral dosage forms: Scientific and regulatory considerations from a clinical pharmacology and biopharmaceutical perspective. In: Ghosh TK and Pfister WR (Eds). Drug Delivery to the Oral Cavity Molecules to Market. NY, USA: CRC Press, 2005: 337-356.

6. Boer D et al. Drug absorption by sublingual and rectal routes. British J Anaesthesia1984; 56: 69-82.

7. Mary Elizabeth RN, Martelli BS. Sublingual and buccal medication administration. Encyclopedia of Nursing and Allied Health, 20050229

8. Lea L. Sublingual Administration. Colon Health 1996; 13.

9. Galey, W.R., H.K. Lonsdale and S. Nacht, 1976. The in vitro permeability of skin and buccal mucosa to selected drugs and tritiated water. J. Investigative Dermatol., 67(6): 713717.

10. Malke, M., S. Shidhaye and V.J. Kadam, 2007. Formulation and evaluation of Oxacarbazine fast dissolve tablets. Indian J. Pharmaceutical Sci., 69(2): 211-214.

11. Jaysukh J Hirani, Dhaval A Rathod, Kantilal R Vadalia. Orally Disintegrating Tablets: A Review. Trop J Pharm Res, April 2009; 8 (2): 161-172.

12. Bhyan Bhupinder, JangraSarita, Formulation and Evaluation of Fast Dissolving Sublingual Films of Rizatriptan Benzoate. Int. J. Drug Dev. \& Res., 2012; 4 (1): 133-143.

13. S Supriya, M Sheetal, P M., K Vilasrao. Fast Disintegrating Palatable Theophylline Tablets For Pediatrics. The Internet Journal of Pediatrics and Neonatology.2007 Volume 9 Number 1.

14.Swapnil L. Patil, Paresh R. Mahaparale, Madhavi A. Shivnikar, Shradha S. Tiwari, Ketan V. Pawar, Prashant N. Sane. Fast Dissolving Oral Films: An Innovative Drug Delivery System. IJRRPAS, 2012; 2(3): 482-496

15.Bala R, Pawar P, Khanna S, Arora S. Orally Dissolving Strips: A New Approach to Oral Drug Delivery System. Int J PharmaInvestig. 2013; 3: 67-76.

16.ArunArya, Amrish Chandra, Vijay Sharma and KamlaPathak. Fast Dissolving Oral Films: An Innovative Drug Delivery System and Dosage Form. Int.J. ChemTech Res. 2010; 2(1): 576- 583.

17. Manjunath B. Mendon and RoopaKarki.Design of Novel Oral Films as Drug Delivery System. Int. J. of Pharm. \& Life Sci. 2013; 4(3): 2425-243

18. Honey Goel, ParshuramRai, VikasRana and Ashok K. Tiwary. Orally Disintegrating Systems: Innovations in Formulation and Technology.Recent Patents on Drug Delivery \& Formulation.2008; 2: 258-274.

19. Farhana Sultana, Mohammad Arafat, Saiful I. Pathan. Preparation and Evaluation of Fast Dissolving Oral Thin Film of Caffeine.IJPBS. 2013; 3(1): 153- 161. 
20.DebjitBhowmik, Chiranjib.B, Krishnakanth, Pankaj, R.MargretChandira. Fast Dissolving Tablet: An Overview. Journal of Chemical and Pharmaceutical Research, 2009; 1(1): 163177.

21.NaziyaKhatoon, N. G. RaghavendraRao, B. Mahipal Reddy. Overview on Fast Dissolving Oral Films. Int. J. Chem. Pharm. Sci., 2013; 1(1): 63-75.

22.R Dixit; S Puthli. J of Controlled Release: (Mumbai, India) Official J of Controlled Release Society, 139(2), 94-107.

23.C. Corniello, Quick dissolving strips: from concept to commercialization, DrugDel. Technol. 6 (2) (2006) 68-71.

24. Prasanna Kumar Desu, B. Brahmaiah, A. Nagalakshmi, K. Neelima, SreekanthNama, ChanduBaburao. An Overview of Rapid Dissolving Films.Asian J.Pharm. Res. 2013; 3(1): $15-23$.

25. JhadeSreekanth, P.K. Lakshmi. Formulation Development of Fast Releasing Oral Thin Films of LevocetrizineDihydrochloride with Eudragit EPO and Optimisation Through Taguchi Orthogonal Experimental Design. International Journal of Pharmaceutical Sciences Review and Research, 2011; 11(1): 115- 123.

26. El-Nabarawi M.A, Makky A.M, ElSetouhy D. A, AbdElmonem R. A and Jasti B.A. Development and Characterization of Ketorolac Tromethamine (Kt) Orobuccal Films.Int J Pharm PharmSci, 2012; 4(4): 186- 193.

27. S. Kishore Kumar, M.V. Nagabhushanam, K.R.S. SambasivaRaoand, D.V.R.N. Bhikshapathi. Formulation Development and In Vivo Evaluation of Zolmitriptan Oral Dissolving Films.Int J Pharm Bio Sci. 2013; 4(3): 638 - 654.

28. Punit B. Parejiya, Rakshit C. Patel, Dharmik M. Mehta, Pragna K. Shelat, Bhavesh S. Barot. Quick Dissolving films of Nebivolol Hydrochloride: Formulation and Optimization by a Simplex Lattice Design. Journal of Pharmaceutical Investigation.2013; 43: 343-351.

29. Cilurzo F, Cupone I, Minghetti P, Selmin F, Montanari L. Fast Dissolving Films Made of Maltodextrins. Eur J Pharm Biopharm, 2008; 70(3): 895-900.

30. Dinge A, Nagarsenker M. Formulation and Evaluation of Fast Dissolving Films for Delivery of Triclosan to the Oral Cavity. AAPS Pharm Sci Tech, 2008; 9(2): 349-56.

31. Chen MJ, Tirol G, Bass C, Corniello CM, Watson G, Sanchez I. Castable Edible Pharmaceutical Films. Drug Del Tech, 2008; 8(6): 35-41.

32. Mashru RC, Sutariya VB, Sankalia MG, Parikh PP. Development and Evaluation of Fast Dissolving Film of Salbutamol Sulphate. Drug DevInd Pharm, 2005; 1: 25-34.

33.P. Obermeier, T. Kohr, K. Kramer, K. Kolkkers, Oral, quickly disintegrating film, which cannot be spit out, for an antiemetic or antimigraine agent, U.S. Patent 2008/0213343 A1, Sept 4, 2008.

34.SuneelaProdduturi, Kevin L. Urman, Joshua U. Otaigbe, and Michael A. Repka:Stabilization of Hot-Melt Extrusion Formulations Containing Solid Solutions Using Polymer Blends. AAPS PharmSciTech 2007; 8 ,2:50.

35.Arunarya, Amrish Chandra, Vijay Sharma and Kamala Pathak Fast dissolving Oral films: An innovative drug delivery system and dosage form; International journal of chemtech research ISSN: 0974-4290 vol 2, No1,Jan 2010. Pp 576-583.

36.Bruntonl, Laurence, Lazo S. Johan, Parker L, Goodman and Gilman, The Pharmacolgical Basis of therapeutics, 11th edition, pp-1032.20.Psaty BM, Smith NL, Siscovick DS, Koepsell TD, Weiss NS, Heckbert SR,

37. Health outcomes associated with antihypertensive therapies used as first-line agents. A systematic review and meta-analysis.JAMA 1997, 277, pp-739.

38. Bhyanbhupinder, Jangrasarita. Formulation and evaluation of fast dissolving sublingual films of Rizatryptan Benzoate.Int J Drug Dev\& Res.2012;4(1):133-43 
39.Koland M, Sandeep VP, Charyulu NR. Fast Dissolving Sublingual Films of Ondansetron hydrochloride: Effect of additives on invitro drug release and mucosal permeation. J Young Pharm.2010; 2(3):216-22.

40. Shelke PV, Dumbare AS, Gadhave MV, Jadhav SL, Sonawane AA, Gaikwad DD. Formulation and evaluation of rapidly disintegrating film of Amlodipine besylate. J Drug Del \& Thr.2012;2(2):72-75

41. Shivani Singh et al, "Formulation and evaluation of rapidly disintegrating film of Levocetrizine Hydrochloride”, Scholars Research Library Der Pharmacia Lettre, 2010, 2(2): 434-439.

42.Dinge A, Nagarsenker M, "Formulation and evaluation of fast dissolving films for delivery of triclosan to the oral cavity", AAPS Pharm Sci Tech, 9(2), 349-56, Feb.2008.

43. Mashru RC, Sutariya VB, Sankalia MG, Parikh PP, "Development and evaluation of fast dissolving film of salbutamol sulphate", Drug DevIndPharm, 1, 25-34, 2005.

44.Ghorwade V, Patil A, Patil S, Srikonda K, Kotagiri R, Patel P. Development and evaluation of fast dissolving film of Montelukast sodium. World J Med Pharm \& Bio Sci.2011;1(1):06-12

45.Le Grand B, Panissie A, Perez M, Pauwels PJ, John GW: Zolmitriptan stimulates a $\mathrm{Ca}(2+)$-dependent $\mathrm{K}(+)$ current in $\mathrm{C} 6$ glioma cells stably expressing recombinant human 5HT receptors. Eur J Pharmacol. 2000 Jun 2;397(2-3):297-302.

46.Cilurzo F, Cupone I, Minghetti P, Selmin F, Montanari L, " Fast dissolving films made of maltodextrins", Eur J Pharm Biopharm, 70(3), 895-900, Nov 2008.

47.Ali S, Quadir A, "High molecular weight povidone based films for fast dissolving drug delivery applications", Drug Del Tech, 7(6), 36-43, June 2007.

48.Honary S, Orafai H, "The effect of different plasticizer molecular weights and concentrations on mechanical and thermomechanical properties of free films", Drug DevInd Pham, 28(6), 711-715, 2002.

49.Chen M, Tirol G, Schmitt R, Chien C, Dualeh A, "Film forming polymers in fast dissolve oral films", AAPS Annual meetings-posters and papers, T3200, 2006.

50.WO/2008/040534, Leichs C, Breitenbach A, Lehrke I, Galfetti P, Non mucoadhesive film dosage forms.

51.WO/2005/048980, Shin M, Ahn K, Sung K, Kwon Y, Composition for oral consumable film.

52.Cilurzo, F., I.E. Cupone, P. Minghetti, F. Selmin, L. Montanari, 2008. Fast dissolving films made of maltodextrins. European J. Pharmaceutics and Biopharmaceutics. 70: 895-900.

53. Kunte S, Tandale P. Fast dissolving strips: A novel approach for the delivery of verapamil. J Pharm Bioallied Sci.2010;2(4):325-28.

54. Raju S, Reddy S.P., Kumar A.V., Deepthi A, Reddy S.K, Reddy MVP. Flash release oral films of Metoclopramide hydrochloride for paediatric use: Formulation and in vitro evaluation. J Chem\& Pharm Res.2011;3(4):636-46.

55. Mishra R, Amin A. Formulation and characterisation of rapidly dissolving films of Cetrizine hydrochloride using pullulan as film forming agent. Ind $\mathbf{J}$ Pharm Edu\& Res.2011;45(1):71-77

56.C. Wu, J.W. McGinity, Influence of ibuprofen as a solid-state plasticizer in Eudragit RS 30 D on the physicochemical properties of coated beads, AAPS PharmSciTech. 2 (4) (2001) 24.

57.P. Sakellariou, R.C. Rowe, E.F.T. White, An evaluation of the interaction and plasticizing efficiency of the polyethylene glycols in ethylcellulose and hydro- kypropyl methylcellulose films using the torsional braid pendulum, Int J Pharm. 31 (1986) 55-64.

58.P. Sakellariou, R.C. Rowe, Interactions in cellulose derivative films for oral drug delivery, Prog. Polym. Sci. 20 (1995) 889-942. 
59.N. Kulkarni, L.D. Kumar, A. Sorg, Fast dissolving orally consumable films containing an antitussive and a mucosa coating agent, U.S. Patent 2003/206942, Nov 6, 2003.

60.S. Ali, A. Quadir, High molecular weight povidone polymer-based films for fast dissolving drug delivery applications, Drug Del. Technol. 7 (6) (2007) 36-43.

61.M. Hariharan, A. Bogue, Orally dissolving film strips (ODFS): the final evolution of orally dissolving dosage forms, Drug Del. Technol. 9 (2) (2009) 24-29.

62.H. Sohi, Y. Sultana, R.K. Khar, Taste masking technologies in oral pharmaceuticals: recent developments and approaches, Drug Dev. Ind. Pharm. 30 (2004) 429-448.

63.J. Szejtli, L. Szente, Elimination of bitter, disgusting tastes of drugs and foods by cyclodextrins, Eur. J. Pharm. Biopharm. 61 (3) (2005) 115-125.

64.Cilurzo F, Cupone I, Minghetti P, Selmin F, Montanari L, “ Fast dissolving films made of maltodextrins", Eur J Pharm Biopharm, 70(3), 895-900, Nov 2008.

65.Ali S, Quadir A, "High molecular weight povidone based films for fast dissolving drug delivery applications", Drug Del Tech, 7(6), 36-43, June 2007.

66.Honary S, Orafai H, "The effect of different plasticizer molecular weights and concentrations on mechanical and thermomechanical properties of free films", Drug DevInd Pham, 28(6), 711-715, 2002.

67. Chen M, Tirol G, Schmitt R, Chien C, Dualeh A, "Film forming polymers in fast dissolve oral films", AAPS Annual meetings-posters and papers, T3200, 2006.

68.WO/2008/040534, Leichs C, Breitenbach A, Lehrke I, Galfetti P, Non mucoadhesive film dosage forms.

69.WO/2005/048980, Shin M, Ahn K, Sung K, Kwon Y, Composition for oral consumable film.

70.Cilurzo, F., I.E. Cupone, P. Minghetti, F. Selmin, L. Montanari, 2008. Fast dissolving films made of maltodextrins. European J. Pharmaceutics and Biopharmaceutics. 70: 895-900.

71.Kunte S, Tandale P. Fast dissolving strips: A novel approach for the delivery of verapamil. J Pharm Bioallied Sci.2010;2(4):325-28.

72.Raju S, Reddy S.P., Kumar A.V., Deepthi A, Reddy S.K, Reddy MVP. Flash release oral films of Metoclopramide hydrochloride for paediatric use: Formulation and in vitro evaluation. J Chem\& Pharm Res.2011;3(4):636-46.

73.Mishra R, Amin A. Formulation and characterisation of rapidly dissolving films of Cetrizine hydrochloride using pullulan as film forming agent. Ind $\mathrm{J}$ Pharm Edu\& Res.2011;45(1):71-77

78.Desu P, Sahu M. Formulation and evaluation of fast dissolving films of Zolmitriptan. Int Res J Pharm.2012;3(5):373-76.

79.Rathi et al ,A Brief Review on Oral Film Technology; International Journal Of Research In Ayurveda \& Pharmacy ; 2011, 2(4), 1138-1147.

80.Arun A et al , Fast dissolving oral films: An innovative drug delivery system and dosage form. International Journal of Chem Tech Research; 2010, 2(2), 576-583.

81.Mitali M Vaidya et al ,Oral fast dissolving drug delivery system: A modern approach for patient compliance. World Journal of Pharmaceutical Research; 2013, 2, 558-577 